\title{
Article \\ Synthesizing Data to Classify and Risk Assess Vegetation Types for Regulations in Inland New South Wales Australia
}

\author{
John Benson
}

check for updates

Citation: Benson, J. Synthesizing Data to Classify and Risk Assess Vegetation Types for Regulations in Inland New South Wales Australia. Land 2021, 10, 1050. https://doi.org/ 10.3390/land10101050

Academic Editors: Patrick J. Comer and Reed F. Noss

Received: 27 August 2021

Accepted: 2 October 2021

Published: 7 October 2021

Publisher's Note: MDPI stays neutral with regard to jurisdictional claims in published maps and institutional affiliations.

Copyright: (C) 2021 by the author. Licensee MDPI, Basel, Switzerland. This article is an open access article distributed under the terms and conditions of the Creative Commons Attribution (CC BY) license (https:// creativecommons.org/licenses/by/ $4.0 /)$.
60 Boorawine Terrace, Callala Bay, NSW 2540, Australia; jsbecodirections@outlook.com

\begin{abstract}
From 1998, land-use regulations in New South Wales Australia referred to risk status of plant community types and abiotic landscapes. Lacking was a uniform vegetation classification for $77 \%$ of NSW comprising the inland arid, semi-arid and cropping agricultural zones: regions that contain patchy floristic plot data. In response, 562 plant communities, mainly at levels 8 in the IVC, were classified by synthesizing plot-based analyses, qualitative descriptions, maps, extensive field checks, new field samples and peer review. Qualitative information was vital to complete a thorough classification. Each type was assigned a risk category based on six risk assessment criteria developed prior to IUCN RLE. Occurrences in protected areas were audited and related to original extent yielding a protected area/adequacy code. Results were used in land change assessment tools and contributed to the listing of 40 threatened ecological communities under biodiversity laws. Two mapping methods attained different levels of reliability. Applying risk criteria to coarse versus fine levels in typologies can produce different results. Mid-to fine level global hierarchies best suit ecosystem risk assessment.
\end{abstract}

Keywords: vegetation classification; land use regulation; ecosystem risk assessment

\section{Introduction}

Environmental assessment and land use regulation can refer to risk and conservation status of classified units, from the gene to the biosphere [1-3]. Public concern over high rates of native vegetation clearing in rural zones in the Australian state of New South Wales (NSW) led, in 1995, to a jurisdiction-wide land clearing planning control, superseded by the NSW Native Vegetation Conservation Act 1998, then the NSW Native Vegetation Act 2003 and most recently the NSW Biodiversity Conservation Act 2016. For the first 13 years of the regulations land use change proposals required landowners to develop property vegetation plans (PVPs) assessed by field checks and spreadsheet calculation tools [4,5]. At the core of the regulations was a requirement to assess the status of plant community types (PCTs). By 2002 an abiotic 500+-unit landscape classification covered NSW [6], also used in the land assessment tools, however, lacking was a uniform NSW-wide, fine thematic vegetation classification and status assessment.

Numerous legacy vegetation surveys and maps have been produced in NSW over 70 years with inconsistent attribution and scale [7,8]. A seminal book on Australian vegetation was published in 1981 [9] listing plant assemblage groupings in a hierarchy providing a detailed continental overview.

To meet NSW regulatory and general conservation planning needs, in 1999, the NSW Herbarium at the Royal Botanic Gardens Sydney initiated the NSW vegetation classification and assessment database project (NSWVCA) [8] that builds on the classification initiated in the above-mentioned book. Conceptually, the NSWVCA aligns with The Nature Conservancy's 1998 vegetation classification of the United States [10].

The objectives of the NSW project included: classifying NSW native vegetation to the plant association hierarchical level [11] equivalent to level 8 in the International Vegetation Classification (IVC) [12], store information on each classified plant community type (PCT) 
in a database to facilitate queries, assign World Conservation Union (IUCN)-like risk categories to each classified unit, list threatening processes and collate representations in IUCN-defined protected areas [13] for an assessment of protected area adequacy.

\section{Study Area}

Due to accelerating ecosystem decline caused by intensification of agriculture in the drylands of south-eastern Australia, the project focused on the inland Western Slopes and Western Plains sections of NSW, Figure 1.

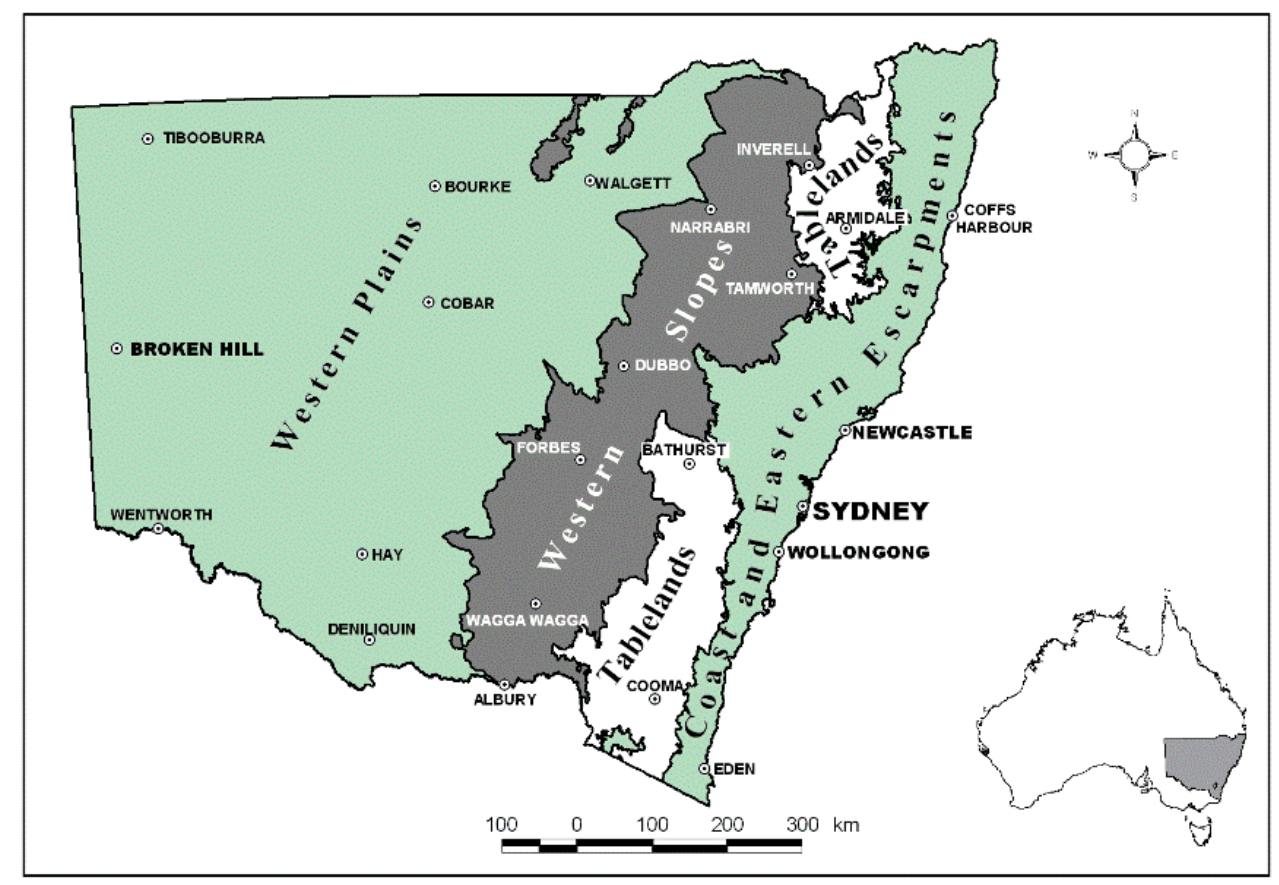

Figure 1. The Western Slopes and Western Plains comprising inland NSW, source [8].

Inland NSW is divided into 11 Australian bioregions [14] and is approximately 61 million hectares in size, corresponding to $77 \%$ of NSW. The vegetation varies from chenopod shrublands, desert gibber grassland and Acacia shrublands in the arid zone receiving $200 \mathrm{~mm}$ annual precipitation, to Eucalyptus-dominated woodlands and forests with small patches of "semi-arid" rainforests on the Western Slopes receiving up to $700 \mathrm{~mm}$ annual precipitation. Temperate native grasslands occur on loam to clay alluvial soils in the agricultural zone and are highly threatened. Hummock grassland and Eucalyptus mallee shrubland are a feature on sandy soil mostly in drier regions with some mallee occurring on rises on the Western Slopes. Vegetation patterns, physical features, climate and land use are described in three published iterations of the NSWVCA that progressively covered the study area [15-17].

\section{Methods}

The vegetation classification, risk assessment criteria and description of methods applied in the vegetation classification along with the NSWVCA 90-information field database are described [8] at https:/ / www.rbgsyd.nsw.gov.au/getmedia/623f3dc8-99ba-421f-a9 09-638dc07e1064/Cun9Ben331.pdf.aspx (accessed on 26 August 2021). The 89 information fields are outlined in section A of Supplementary Materials S1. They include: Plant Community Type (PCT) number, scientific name, common name, level of classification, formation group, vegetation structure, adequacy of plot data, confidence, photographs and captions, relationship to ecological classifications in adjoining jurisdictions, soil, substrate, landform, presence in bioregions, subregions and local government areas, extent at time of pre-European settlement (1788), current extent, extent recorded in each protected area, statistics on proportion in protected areas compared to 1788 and current extent, 
total protected area, list of threatening processes and appropriate fire regime based on available research.

Assignment of a risk category was based on application of six risk criteria developed specifically for the NSWVCA project [8] reflecting the IUCN species risk criteria [18]. The risk categories and risk criteria are outlined in section B in Supplementary Materials S1. These criteria are conceptually similar but predated the IUCN Red List of Ecosystems (RLE) risk assessment criteria for ecosystems $[19,20]$. Each PCT was assigned a risk category: Presumed Extinct, Critically Endangered, Endangered, Vulnerable, Near Threatened and Least Concern. The NSWVCA criteria, Supplementary Materials S1, are: 1. Decline in geographic distribution (area of occupancy and occurrence) with thresholds from fragmentation theory [21,22]; 2. Small areas of occupancy under threat; 3. Decline in functionally important species; 4. Reduction in community integrity: condition and recoverability; 5. Rate of continuing detrimental change; 6. Quantitative analysis on probability of extinction. Criteria 3 and 4 usually require expert judgement. Criterion 6 needs sufficient data to underpin models.

The protected area adequacy codes assigned to each PCT are derived from Australian regional forest assessment rules for gauging the adequacy of representation of forest types in protected areas [23], outlined in item 78, Section A in Supplementary Materials S1.

A combined risk category/protected area code reflects overall conservation status. Examples of queries are: 1: "list endangered (EN) PCTs in a particular bioregion on a certain soil"; 2: "list PCTs with $<30 \%$ remaining extent in a specific region". The latter became a key decision threshold for vegetation clearing applications.

Outputs from analyses of floristic plot surveys that cover parts of the study area were favored in developing the classification but as discussed below there are gaps in these sets of data. In NSW, floristic surveys apply modified Braun-Blanquet scales [24-26] to species in plots that are subjected to cluster analyses [27] and often fidelity analyses [28], to generate and describe plant communities. Hierarchies can be selected at different levels of disassociation measures in analyses [29].

Approximately 41,000 floristic plots are in the eastern $23 \%$ of NSW [30], reflecting decades of forest and coastal land assessments. In comparison, approximately 27,000 plots sample the larger inland sections that comprise 77\% of NSW [30]. Most inland floristic surveys sample vegetation in conservation reserves with a few regional datasets [8], leaving significant plot data gaps, Figure 2. To complete plot sampling over the 61 million hectares of inland NSW was impractical given available resources and short-term need for a vegetation classification and status assessment for land use regulations.

A 1400 plot analysis of available data was completed in the Nandewar Bioregion in the eastern side of the study area to classify a complex array of forests and woodlands [31]. To fill data gaps over much of the remaining bioregions, hundreds of sources of information on native vegetation were interrogated: reports, descriptions, maps, and expert advice. GIS vegetation maps yielded extent statistics, including for protected areas.

During 60,000 km of field traverses, 1500 new floristic plots were sampled, often in vegetation previously lacking data. These samples underpinned the classification and description of some types. Photographs of sample sites were taken during road traverses, GPS-coded and registered to PCTs. Up to three images of each PCT were linked to the database, outlined in Supplementary Materials S1. 


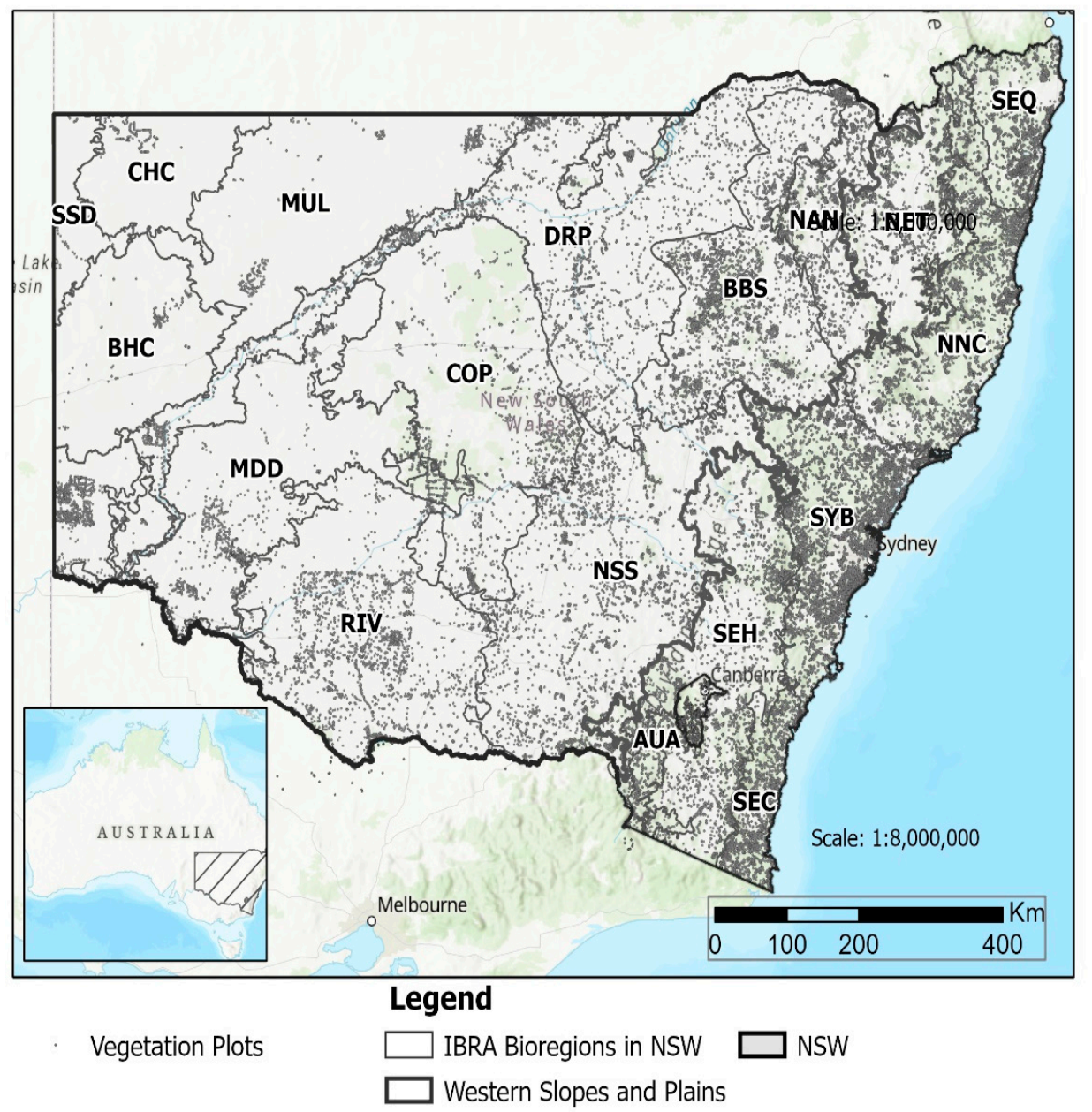

Figure 2. Distribution of floristic plot data (dots) in 18 IBRA bioregions [14] in NSW. Plot data are patchy across most of inland NSW that comprises 11 bioregions: NSS, NAN, BBS, DRP, RI, COP, MUL, MDD, BHC, CHC and SSD.

\section{Results}

A total of 562 PCTs were classified, risk-assessed, and audited for occurrences in protected areas. A range of attributes were assigned including indicative species in three strata, geography, abiotic features and legal status, Table Supplementary Materials S2. Most PCTs are classified to plant association level, level 8 IVC hierarchy [12] with a few exceptions recorded at the alliance, level 7 in the IVC. The PCTs are grouped under 23 Formation Groups [8] derived from [9] that equate to Macrogroup level 5 IVC [12].

PCTs based on floristic data analysis are concentrated in parts of the Riverina bioregion, Scotia mallee in the far southwest corner of the MDD bioregion, the Pilliga Forests in the BBS bioregion, the Murray River corridor on the NSW southern border with Victoria and in numerous conservation reserves and surroundings. Large areas of the COP, MDD, DRP, MUL, CHC, BHC and SSD bioregions remain poorly plot sampled.

Vegetation types in the arid zone far inland regions are more intact, except for PCTs impacted by lakebed cropping and opportunistic clearing, hence PCTs in these regions contain less threatened PCTs. However, many PCTs in these drier regions are degraded by over-grazing by domestic stock and feral animals, particularly goats. A lack of regeneration of plant species is a long-term threat [15]. Some arid-zone PCTs are assessed as vulnerable, Table Supplementary Materials S2, but are not formally listed as threatened ecological communities (TECs) under NSW or Federal en67vironmental regulations.

A total of 233, approximately $40 \%$, of the inland NSW PCTs are assessed by the NSWVCA risk criteria, as threatened: either CR, EN or VU, Table 1, with examples in 
Figures 3 and 4. Some of the 37 CR-graded PCTs are highly restricted, including artesian mound springs in the far inland and ln the Western Slopes, remnant rainforest-derived vegetation. The risk assessments assisted with nominations and listings of 13 threatened ecological communities (TECs) in the Australian Government Environmental Protection and Biodiversity Conservation Act 1999 [32] and 27 in the NSW Government Biodiversity Conservation Act 2016 [33].

Table 1. Risk categories assigned to 562 inland NSW PCTs applying NSWVCA risk criteria outlined in Supplementary Materials S1 producing results in Supplementary Materials S2.

\begin{tabular}{cc}
\hline Threat Code & Number \\
\hline Critically endangered (CR) & 37 \\
\hline Endangered (EU) & 95 \\
\hline Vulnerable (VU) & 101 \\
\hline Near Threatened (NT) & 153 \\
\hline Least Concern (LC) & 176 \\
\hline Total & 562 \\
\hline
\end{tabular}

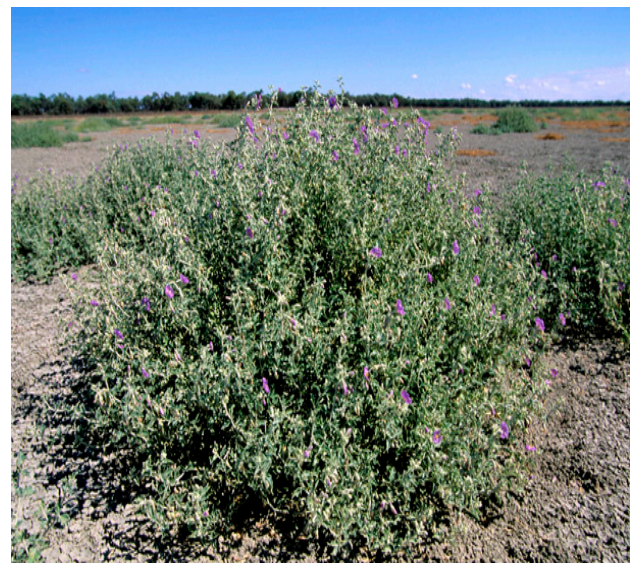

(a)

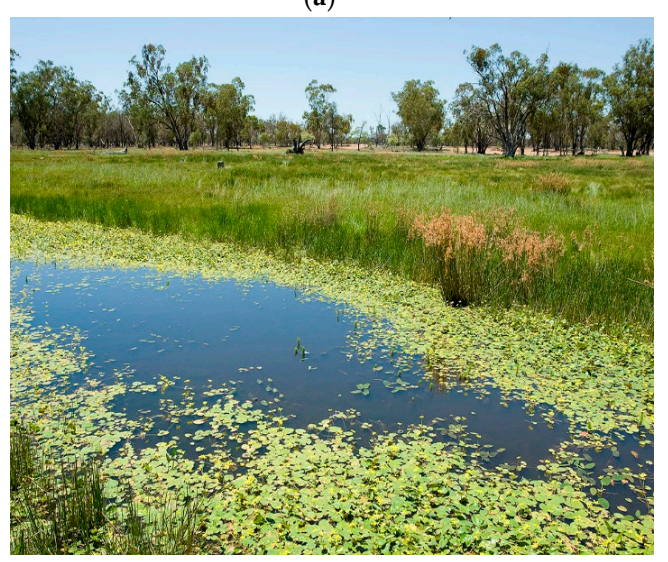

(c)

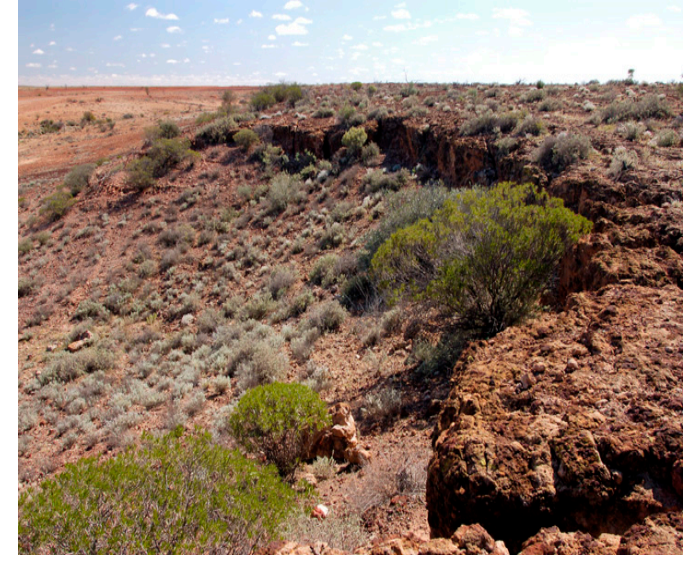

(b)

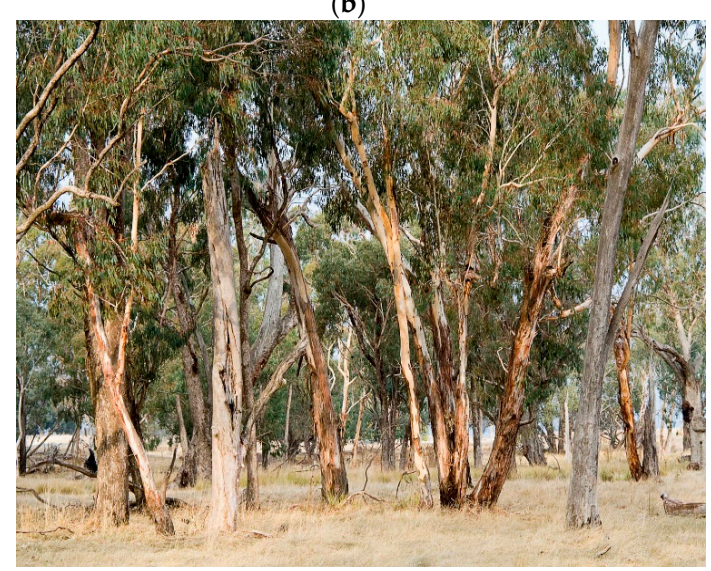

(d)

Figure 3. Four distinct inland NSW PCTs defined qualitatively with limited plot samples. These PCTs could be overlooked in vegetation classification generated solely though analyses of available plot data: (a) PCT 189 Lakebed cracking clay ephemeral forbland in the arid zone, threatened by lakebed cropping, Near Threatened. (b) PCT 132 Silcrete scarp shrubland in Sturt National Park in the arid zone, grazing by feral and native animals limiting regeneration of some species, Least Concern. (c) PCT 364 Sodic soils wetland in the Yetman-Yelarbon region, Brigalow Belt South Bioregion, Near Threatened. (d) PCT 304 Candlebark (Eucalyptus rubida)-Apple Box (Eucalyptus bridgesiana) open forest on granite, upper NNS bioregion, part of a listed NSW TEC, Critically Endangered. 


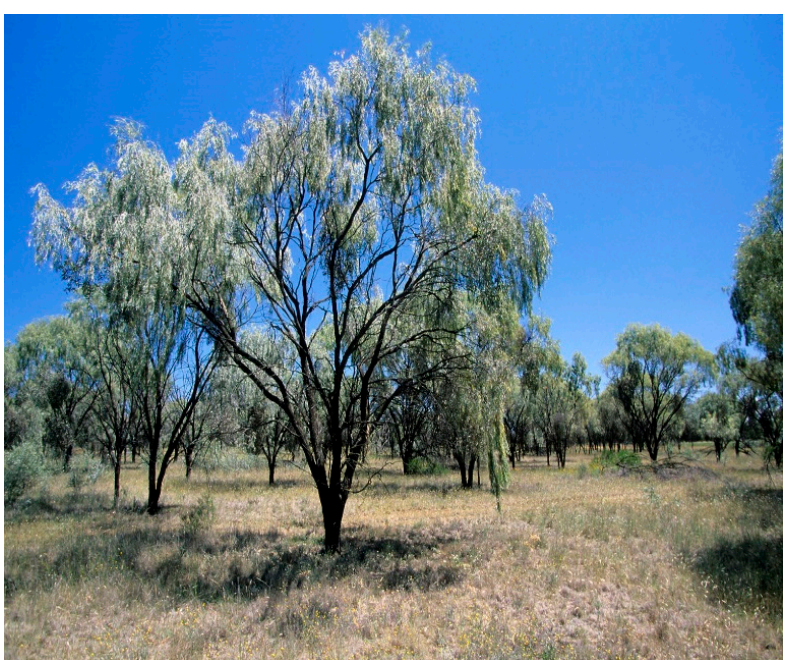

(a)

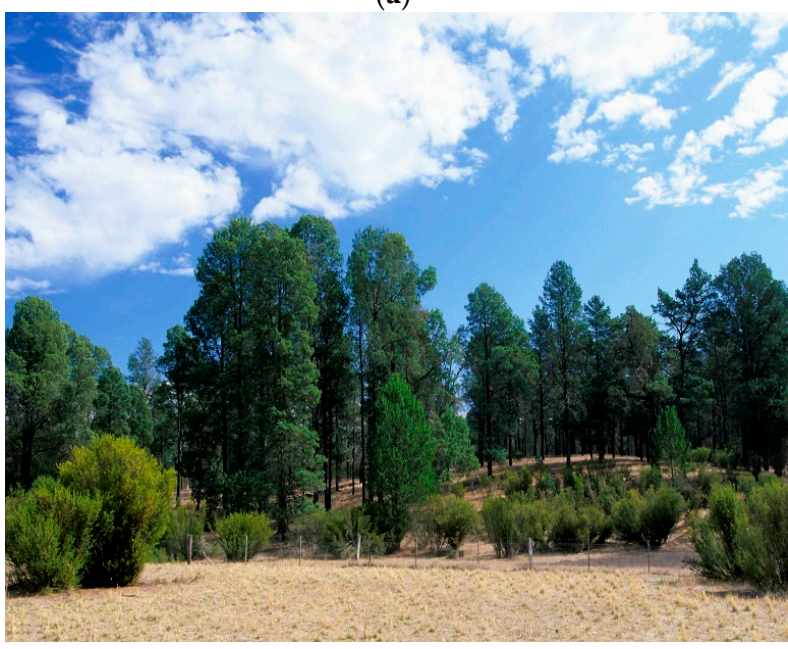

(c)

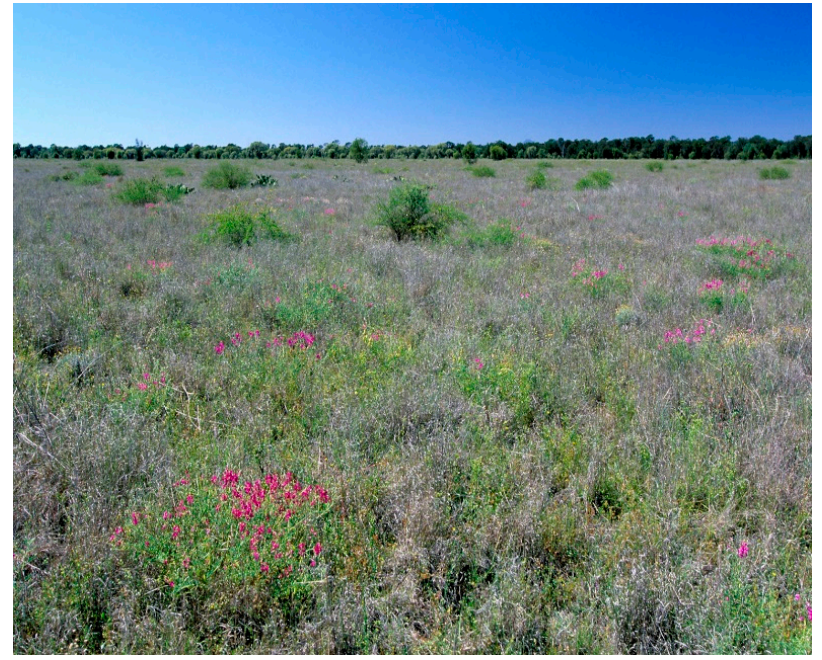

(b)

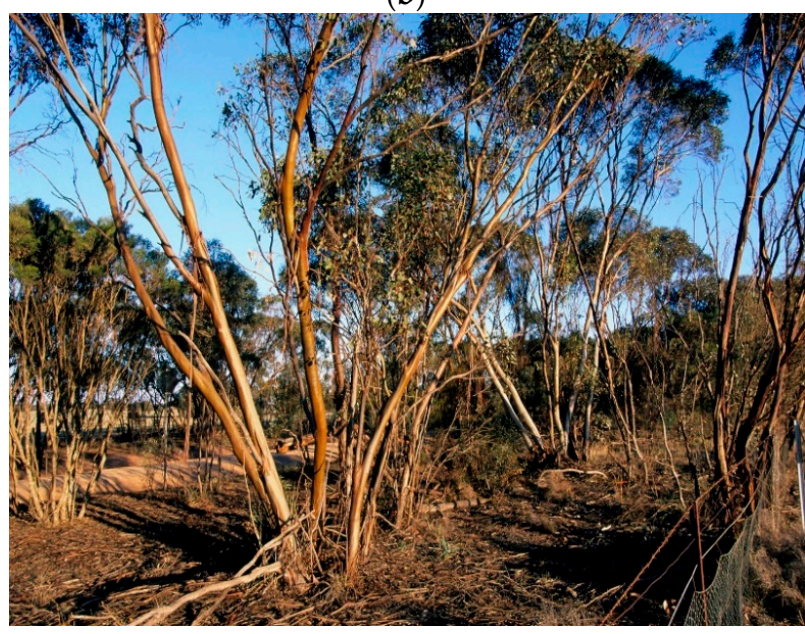

(d)

Figure 4. Four threatened inland NSW PCTs defined quantitatively in regional or local-scale floristic plot data analyses: (a) PCT 26 Myall (Acacia pendula) grassy woodland in the Riverina Bioregion, originally widespread on alluvial clay soils but mostly cleared for agriculture, listed NSW and Federal TEC. (b) PCT 52 Mitchell Grass (Astrebla spp.)—Bluegrass (Dichantheum) grassland in the BBS and DRP bioregions, over the last 50 years most of its extent has been cultivated for crops with limit areas remaining in good condition, listed NSW and Federal TEC. (c) PCT 19 Murray Pine (Callitris gracilis subsp. murrayensis) source-bordering sand dune woodland, Riverina bioregion, original extent restricted, partly cleared for grazing and impacted by grazing by including introduced rabbits, listed NSW and Federal TEC. (d) Blue-leaved Mallee (Eucalyptus polybractea) mallee shrubland NSS bioregion, restricted extent, mainly cleared, small patches in some reserves, listed NSW TEC.

The NSWVCA data were transferred into the NSW Government vegetation classification database system, part of a current-day BioNet Information System that also houses information systems for floristic plot data and vegetation maps [34]. End uses of the results were assimilated in decision-support tools [5] for assessing land use change, including land clearing, conservation planning and education, Figure 5. Up until 2012, development applications for locations containing PCTs coded CR, EN or with less than $30 \%$ remaining were most often refused or modified by regulation administrators. 


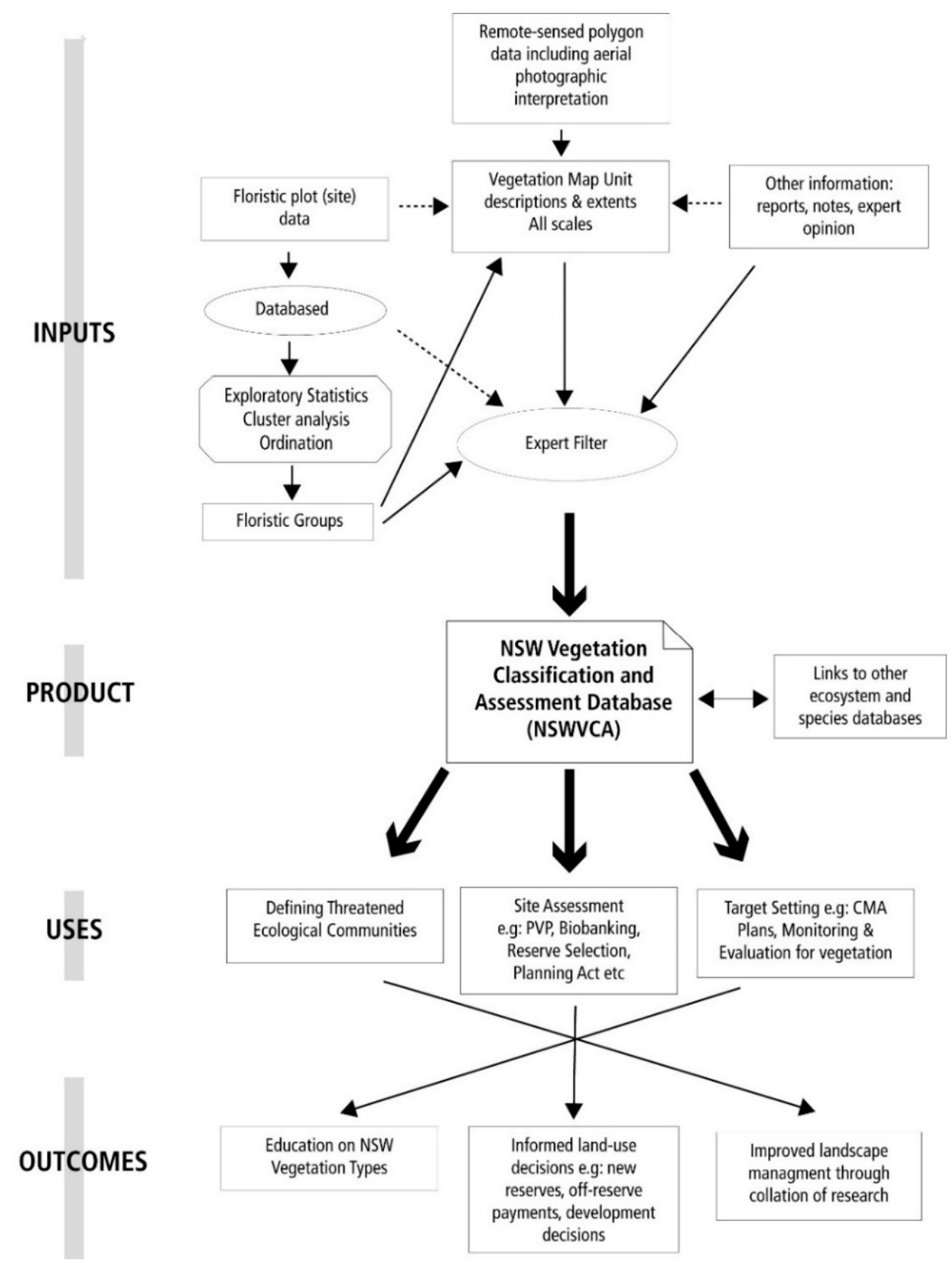

Figure 5. Inputs, uses and outcomes of the NSWVCA project. Rectangles are inputs and outcomes, ovals are processes, truncated rectangle indicates quantitative analysis tools, solid arrows indicate firm paths, hatched arrows weaker paths. Vegetation compositional change caused by land management and climate change will require revision of inputs and products.

Comparison of the NSWVCA risk criteria [8], Supplementary Materials S1, and IUCN RLE criteria v 1.1 [20] to ten structurally different PCTs highlights reasonable congruence between the two schemes, Table 2. Both sets of criteria contain similar parameters but the NSW inland PCT risk assessment [8] extend to categorizing Near Threatened and Least Concern. Benefits or otherwise of applying risk assessment to different levels in the IVC hierarchy are summarized, Table 3. 
Table 2. Comparison of risk categories applying NSWVCA [8] and IUCN Red List of Ecosystemsv1.1 [20] criteria for ten structurally different inland NSW Plant Community Types. Protected area (PA) codes are defined in Supplementary Materials S1.

\begin{tabular}{|c|c|c|c|c|c|c|}
\hline PCT ID & Common Name & $\begin{array}{l}\text { Remaining } \\
\text { Pre-1788 \% }\end{array}$ & PA/1788 \% & $\begin{array}{l}\text { Adequacy } \\
\text { Protected }\end{array}$ & VCA Risk & IUCN v1.1 RLE Risk \\
\hline 2 & $\begin{array}{c}\text { River Red } \\
\text { Gum tall forest }\end{array}$ & 86.00 & 9.37 & $3 a$ & $\begin{array}{l}\mathrm{VU} \\
3,4,5\end{array}$ & $\begin{array}{c}\mathrm{VU} \\
\mathrm{C} 2 \mathrm{~b}, \mathrm{D} 2 \mathrm{~b}\end{array}$ \\
\hline 35 & $\begin{array}{l}\text { Brigalow } \\
\text { forest }\end{array}$ & 10.00 & 0.43 & $5 a$ & $\begin{array}{l}\mathrm{CR} \\
1,4\end{array}$ & $\begin{array}{c}\mathrm{CR} \\
\mathrm{A} 3, \mathrm{~A} 2 \mathrm{~b}\end{array}$ \\
\hline 55 & BBS Belah woodland & 17.00 & 0.37 & $5 a$ & $\begin{array}{c}\text { EN } \\
1,2,4,5\end{array}$ & $\begin{array}{c}\mathrm{CR} \\
\mathrm{A} 2 \mathrm{~b}, \mathrm{~A} 3\end{array}$ \\
\hline 66 & Mound Spring wetland & 3.00 & 0 & $5 c$ & $\begin{array}{c}\mathrm{CR} \\
2,4,5\end{array}$ & $\begin{array}{c}\text { CR } \\
\text { B2a, C1 }\end{array}$ \\
\hline 102 & $\begin{array}{c}\text { Liverpool } \\
\text { Plains grassland }\end{array}$ & 3.00 & 0.65 & $5 a$ & $\begin{array}{c}\mathrm{CR} \\
1,4,5\end{array}$ & $\begin{array}{c}\mathrm{CR} \\
\mathrm{A} 3, \mathrm{~A} 2 \mathrm{~b}\end{array}$ \\
\hline 157 & $\begin{array}{l}\text { Riverina Bladder } \\
\text { Saltbush shrubland }\end{array}$ & 40.00 & 12.98 & $5 a$ & $\begin{array}{l}\mathrm{VU} \\
1,4,5\end{array}$ & $\begin{array}{c}\mathrm{VU} \\
\mathrm{A} 2 \mathrm{~b}, \mathrm{~A} 3, \mathrm{D} 3\end{array}$ \\
\hline 177 & $\begin{array}{l}\text { Blue Mallee } \\
\text { shrubland }\end{array}$ & 13.00 & 12 & $4 a$ & $\begin{array}{c}\text { EN } \\
1,2,3\end{array}$ & $\begin{array}{l}\text { EN } \\
\text { A3 }\end{array}$ \\
\hline 285 & $\begin{array}{l}\text { Broad-leaved } \\
\text { Sally forest }\end{array}$ & 87.00 & 17.13 & $5 b$ & $\begin{array}{l}\text { EN } \\
2,4\end{array}$ & NA \\
\hline 317 & $\begin{array}{c}\text { Currawang tall } \\
\text { shrubland }\end{array}$ & 13.00 & 0.01 & $3 b$ & $\begin{array}{l}\mathrm{LC} \\
1,4\end{array}$ & NA \\
\hline 590 & $\begin{array}{l}\text { Nandewar White } \\
\text { Box woodland }\end{array}$ & 13 & 0.01 & $5 a$ & $\begin{array}{c}\text { EN } \\
1\end{array}$ & $\begin{array}{c}\text { EN } \\
\mathrm{A} 1, \mathrm{D} 1\end{array}$ \\
\hline
\end{tabular}

Table 3. Advantages and disadvantages of applying risk assessment to the International Vegetation Classification [12]: $\mathrm{A}=$ upper levels, $\mathrm{B}=$ middle levels, $\mathrm{C}=$ lower levels.

\begin{tabular}{|c|c|c|}
\hline IVC Levels & Advantages & Disadvantages \\
\hline $\begin{array}{l}\text { A1. Formation } \\
\text { A2. Formation Subclass } \\
\text { A3. Formation }\end{array}$ & $\begin{array}{l}\text { Global scale } \\
\text { Limited units to classify and risk assess } \\
\text { Rapid overview with remote sensing } \\
\text { Addresses large-scale function }\end{array}$ & $\begin{array}{c}\text { Classification based on vegetation growth forms so a } \\
\text { very poor surrogate for species } \\
\text { Components of many units } \\
\text { likely to contain different level of risk } \\
\text { Could be misused in conservation programs }\end{array}$ \\
\hline B4. Division & $\begin{array}{l}\text { Continental scale of growth forms and diagnostic } \\
\text { species reflecting broad climatic, edaphic features }\end{array}$ & $\begin{array}{l}\text { Coarse surrogate for species heterogeneity } \\
\text { Components of many units likely } \\
\text { to contain different levels of risk }\end{array}$ \\
\hline B5. Macrogroup & $\begin{array}{c}\text { Sub-continental scale } \\
\text { Likely to correlate to broad ecosystem function }\end{array}$ & $\begin{array}{l}\text { Coarse correlation to species } \\
\text { Not suitable for local scale assessment }\end{array}$ \\
\hline B6. Group & $\begin{array}{c}\text { Regional scale with dominant } \\
\text { plant species included in description } \\
\text { Likely to correlate with regional ecosystem function } \\
\text { such as hydrology and fire } \\
\text { Mappable using various imagery }\end{array}$ & $\begin{array}{l}\text { Moderate correlate to species } \\
\text { Component units likely to } \\
\text { have inconsistent risk levels }\end{array}$ \\
\hline C7. Alliance & $\begin{array}{l}\text { Subregional scale at which } \\
\text { some land use decisions are made } \\
\text { Moderately similar species composition so reasonable } \\
\text { surrogate for species and fine level ecosystem function } \\
\text { Risk assessment likely to be similar across range }\end{array}$ & $\begin{array}{l}\text { Requires sound data to diagnose } \\
\text { characteristic species in main strata } \\
\text { Mapping requires extensive field work }\end{array}$ \\
\hline C8. Association & $\begin{array}{c}\text { Local scale at which many land use decisions are made } \\
\text { Finest homogeneity, therefore, } \\
\text { most conservative surrogate for species } \\
\text { Risk assessment same across range } \\
\text { and some correlation with species risk assessments } \\
\text { Basis for lumping into coarser units }\end{array}$ & $\begin{array}{l}\text { Requires detailed data and knowledge to classify } \\
\text { diagnostic species in all strata } \\
\text { Mapping units requires extensive ground checking } \\
\text { and high resolution imagery; modelling from plots } \\
\text { generally unreliable }\end{array}$ \\
\hline
\end{tabular}




\section{Discussion}

The rapid decline in ecosystems across the world since WWII has led to the development of global approaches to risk assessment of species [18] and for ecosystems in the IUCN RLE scheme $[19,20]$. The NSWVCA risk criteria were developed a decade before the IUCN RLE and were presented to IUCN Congresses to stimulate the development of a global protocol.

A prerequisite to applying any ecosystem risk assessment scheme is classifying units from abiotic features, assemblages of species, attributes on function or combinations of these. A benefit of the IVC [12] scheme is its standardized definitions of eight levels in vegetation classification for terrestrial biomes. The fine-themed IVC level 8 inland NSW vegetation classification was simultaneously classified, and risk assessed. Experts developing the classification often understand threats, so they can apply risk criteria to classified units. The results suit local to regional scale applications of land use planning and application of regulations.

Since floristic plot data are absent from large parts of inland NSW, over most of Australia and large portions of the world [35], relying solely on these data where there are regions with substantial data gaps, can result in depauperate ecological classifications in which distinct habitats are often left out. While approximately half of inland NSW classification is derived fully or in part from data analyses from well-sampled locations, Figure 4, other information was critical to describing a fuller range of floristic variation, Figure 3. A similar approach to synthesizing multi-sources of data to develop vegetation classifications and maps was applied to produce forest type maps in Italy [36] and regional ecosystems in Queensland, Australia [37].

The inland NSW classification has been validated independently through recent floristic surveys that delivered similar floristic compositions [29,38,39]. An option for identifying less quantitative-derived units in a classification is to follow the US vegetation classification terminology of labelling them "provisional" [40]. The minimum cost of a wellstratified quantitative flora survey to adequately plot-sample the vegetation variation across inland NSW is estimated as $>$ US $\$ 20$ million, over decades, assuming 40,000 additional plots at $\$ 500$ per plot, updated from [41]. This covers field sampling, species identification, databasing, the records, data analysis, vegetation description and risk assessment of the classified units.

An aspect often ignored in vegetation classification and for that matter risk assessment, are temporal states or synusiae [42] that arise in response to climatic variability, common in drylands such as the interior of Australia [43]. If these temporary assemblages are sampled in separate floristic surveys during different weather patterns, and then combined into a single dataset for a wider-scale data analysis or model, the results are likely to be confounded: with implications for assigning risk to the classified units.

Irrespective of complications in vegetation classification, such as transitional states, developing a classification of vegetation types before mapping increases transparency in linkage between aspatial and spatial data $[35,44]$. The inland NSW PCTs have been mapped using two different methods. One employed expert 3-D aerial photographic interpretation of high resolution digital airborne imagery (Leica ADS40/80). Map polygons were entered directly into GIS. This method of mapping the PCTs has covered conservation reserves, including important wetlands [45,46] and has been applied to map 100 inland NSW PCTs over 2.2 million hectares of agricultural land in the highly fragmented NSS bioregion [47]. The results were validated as approximately $45 \%$ accurate to the correct PCT but importantly all defined PCTs were captured in the spatial output. The second mapping method aimed to rapidly produce a jurisdictional vegetation type map [48] by integrating pattern recognition [49] of satellite and airborne imagery with GAM-like modelling [50,51]. Independent validation of this method indicates that it has a low accuracy of less than $20 \%$ [52] in depicting the correct PCT in polygons. It resulted in complex map polygons that appear to reflect disturbance as much as floristic assemblage. Many PCTs were left out due to insufficient sample data to support models. 
The reliability of vegetation maps impacts risk assessment, for example, in calculating the areas of extent or occupancy in risk criteria. It is possible to produce reliable regional vegetation maps. An example from two decades ago is a map that attained $>90 \%$ accuracy in depicting classified plant communities through traditional wet film aerial photographic interpretation and extensive field checking [53]. The US Park Service sets $80 \%$ as an accuracy standard for mapping vegetation types in its reserves [54]. Poignantly, local scale biodiversity assessment and vegetation restoration require comprehensive classification and reliable maps [55,56].

Concerning risk assessment, the level of congruence in the comparative results of applying the relatively qualitative NSWVCA risk criteria [8] to the IUCN RLE criteria $[19,20]$, Table 2, reflect similar thresholds and criteria attributes applied in the two schemes. The NSWVCA scheme, however, applies criteria beyond the threat categories CR, EU and VU as it codes Near Threatened (NT) and Least Concern (LC) categories, therefore assessing the threat status of all classified units.

Species heterogeneity generally increases with coarser hierarchical levels or scales [2,3], Table 3, with implications for selecting a classification level for ecosystem risk assessment. Risk assessments can apply across hierarchy and scales [57]. Hierarchical levels can affect the application of IUCN RLE criterion B area definitions for prescribing "restricted ecosystem" and subsequent assessment of changes in area of occupancy (AOO) and area of extent (EOO). The entire distribution of some inland NSW PCTs, Table Supplementary Materials S2, as classified at a fine thematic level, occupy small enough areas to satisfy criterion B's restricted ecosystem threshold. Yet some are not threatened based on application of condition and remaining extent thresholds. An example is PCT63 Spiny Lignum-Slender Glasswort saline wetland on lake edges in the semi-arid and arid zones. It is assessed as Near Threatened. This scenario is less of an issue with most of listed Australian TECs that tend to comprise multiple PCTs and are more akin to hierarchical levels 5-7 in the IVC [12]. This raises a question: are there "sweet spot" hierarchical levels for applying ecosystem risk assessment criteria?

Applying global scale classifications, maps and risk assessments at finer scales can erode the value of detailed local assessments of complex ecosystems [58]. Product class guidelines could assist the selection and application of different hierarchical classification or map levels. While risk assessment could be applied to all levels, Table 3, it is open to debate if this is prudent. Coarse level assessment could harm the protection of land and nature by being used to over-ride finer level regional or local assessments. The coarsest levels provide a global overview, whereas the middle levels provide continental to regional scale classification hierarchies that may suite management of ecosystem function and regional environmental planning, and the finest levels can contribute to local land management and are more conservative surrogates for species. The inland NSW vegetation classification was deliberately pitched at a finest level 8, C8 in Table 3, to meet property-scale land use assessment and assist in a fine-filter approach to conservation planning [59,60].

An example of the impacts on risk assessment of lumping finer units to coarse levels for risk assessment is the multi-stemmed Eucalyptus shrubland and woodlands termed "mallee" in Australia. There are 20 mallee PCTs classified for the inland of NSW, some widespread across the inland plains, others restricted to small areas, Table Supplementary Materials S2, [17]. When grouped as one "mallee" unit at IVC 1.3 Formation level, the multicomponent risk level average is Near Threatened or perhaps Vulnerable. Alternatively, when assessing the 20 individual mallee PCTs at the much finer hierarchical levels IVCs 7 or 8, the risk categories vary from Endangered (for example, PCTs 177, 190) to Least Concern (for example, PCTs 172, 176). Lumping ecological units, therefore, can homogenize risk assessment with consequences for setting land and biodiversity protection priorities [58]. A few IVC Formation level units may, however, contain uniform risk categories assigned to component parts - such as temperate grasslands or the Atlantic rainforests of eastern Brazil.

Given these issues, a precautionary approach to ecosystem risk assessment may exclude risk assessment criteria being applied to the most heterogenous classification 
levels, 1-4 in the IVC [12] and 1-3 in the IUCN world typology [61], with exceptions where warranted.

Continued degradation of terrestrial landscapes, exacerbated by climate change outlined in the findings of the sixth IPCC report [62], with predictions that Australian temperatures will rise several degrees by the year 2100, could result in shifts in biotic assemblages, rendering today's vegetation classifications and risk assessments obsolete. Setting aside more land for nature $[63,64]$ will help limit ecosystem and species decline but to minimize degradation across all lands, formal protection should be complemented by evaluation of impacts [65] to ensure ecosystems are managed to maintain composition and function.

Irrespective of the level of hierarchy selected for risk assessment, assessment is often hampered by a lack of reliable quantitative measurements for determining change. Proposals to improve ecosystem risk assessment though quantitative analysis of multiple indicators within conceptual frameworks [66], while attractive, could misfire if imposed on nation-states or regions that lack data. Both the definition and risk assessment of ecosystems, including world typologies, require qualitative input. Expert opinion is provided for with some criteria in the current IUCN RLE guidelines [20]. The inland NSW PCT classification was enriched by regional expert inputs along with peer-review. It also cross-references with regularly used Australian landscape classifications, Supplementary Materials S1 [67-71].

Increased research results will lead to more cases for which there are sufficient data to underpin models, satisfying the quantitative criterion 6 in NSWVCA [8] and criterion E in IUCN RLE $[19,20]$ but in the meantime all information and expertise may be needed to define ecological units and assess risk.

\section{Conclusions}

Classification of species assemblages in the context of landscape features is best done before mapping, as this provides clearer linkages between the two. Risk assessment applied to units at finer levels in hierarchical classifications provides a conservative surrogate for assessing biodiversity in land management. Global-scale classifications and maps provide a "first cut", coarse ecosystem perspective but risk assessments at that scale can be misused if applied to regional or local scales. The combined vegetation classification and risk assessment of the plant communities in inland NSW met a fine hierarchical IVC level 8 in vegetation classification suitable for local property scale decisions and fine filter conservation planning. These units can be lumped into broader groups within hierarchies such as the IVC. For vegetation, it is suggested that IVC levels 5-7 hierarchies are suitable for categorising threatened ecosystems, reflected in the definitions of most of the TECs listed under Australian laws. More research may elucidate the relationships of species/landscape heterogeneity in relation to classification hierarchical level and their application in risk assessment. Given the dearth of data across most of the world to undertake risk assessments, it may be prudent to ensure complex multivariant analyses of combinations of IUCN RLE risk criteria for ecosystem risk assessment does not become mandatory.

Supplementary Materials: The following are available online at https: / www.mdpi.com/article/10 .3390/land10101050/s1, Supplementary Materials S1: Description of the New South Wales Vegetation Classification and Assessment Information System and its Risk Assessment Criteria. Supplementary Materials S2. Descriptions, risk and protected area categories of Plant Community Types in the NSW Western Slopes and Western Plains, updated from [17].

Funding: This research received no external funding.

Data Availability Statement: A copy of the published 90 information-field NSWVCA database and plant community PDF reports for inland NSW bioregions is provided on a DVD in the back cover of the journal publication source [17]. The data are also housed in NSW Government Vegetation Classification Information System at https: / www.environment.nsw.gov.au/research/Visclassification.htm (accessed on 26 August 2021) accessible with permission from the Department of Planning Industry and Environment NSW. 
Acknowledgments: Thanks to two anonymous reviewers and to Nic Gellie for producing Figure 2. From 1999-2013, the NSW National Parks and Wildlife Service and Royal Botanic Gardens Sydney supported the inland NSW vegetation classification and risk assessment project.

Conflicts of Interest: The author declares no conflict of interest.

\begin{tabular}{ll}
\multicolumn{2}{l}{ Abbreviations } \\
AOO & Area of Occurrence \\
CR & Critically Endangered \\
EN & Endangered \\
EOO & Extent of Occupancy \\
IUCN & World Conservation Union \\
IVC & International Vegetation Classification \\
LC & Least Concern \\
NSWVCA & New South Wales Vegetation Classification and Assessment Database \\
PA & Protected Area \\
PCT & Plant Community Type \\
PVP & Property Vegetation Plan \\
RLE & IUCN Red List of Ecosystems \\
TEC & Threatened Ecological Community listed under Australian law \\
NT & Near Threatened \\
VU & Vulnerable
\end{tabular}

\section{References}

1. Jones, M.B.; Schildhaurer, M.P.; Reichman, O.J.; Bowers, S. The new bioinformatics: Ecological data from the gene to the biosphere. Annu. Rev. Ecol. Evol. Syst. 2006, 37, 519-544. [CrossRef]

2. Jax, K. Ecological Units: Definitions and Application. Q. Rev. Biol. 2006, 81, 237-258. [CrossRef]

3. Comer, P.; Faber-Langendoen, D.; Evans, R.; Gawler, S.; Josse, C.; Kittel, G.; Menard, S.; Pyne, M.; Reid, M.; Schulz, K.; et al. Ecological Systems of the United States: A Working Classification of U.S. Terrestrial Systems; NatureServe: Arlington, VA, USA, 2003.

4. Oliver, I. A framework and toolkit for scoring the biodiversity value of habitat, and the biodiversity condition within the context of biodiversity conservation. Ecol. Manag. Restor 2004, 5, 75-78. [CrossRef]

5. BioMetric Version 1.8: A Terrestrial Biodiversity Assessment Tool for the NSW Property Vegetation Plan Developer Operational Manual. Available online: https://www.environment.nsw.gov.au/resources/pestsweeds/biometric_manual_1_8.pdf (accessed on 26 August 2021).

6. NSW Ecosystems Study: Background and Methodology. Available online: https://www.environment.nsw.gov.au/resources/ conservation/EcosystemsMethodology.pdf (accessed on 26 August 2021).

7. Schmid, R.; Keith, D. From Ocean Shores to Desert Dunes: The Native Vegetation of New South Wales and the ACT. TAXON 2005, 54, 1120. [CrossRef]

8. New South Wales Vegetation Classification and Assessment: Introduction-The Classification, Database, Assessment of Protected Areas and Threat Status of Plant Communities. Available online: https://www.rbgsyd.nsw.gov.au/getmedia/623f3dc8-99ba-42 1f-a909-638dc07e1064/Cun9Ben331.pdf.aspx (accessed on 26 August 2021).

9. Beadle, N.C.W. The Vegetation of Australia; Cambridge University Press: Cambridge, UK, 1981.

10. Grossman, D.H.; Faber-Langendoen, D.; Weakley, A.S.; Anderson, M.; Bourgeron, P.; Crawford, R.; Goodin, K.; Landaal, S.; Metzler, K.; Patterson, K.D.; et al. International Classification of Ecological Communities: Terrestrial Vegetation of the United States; The Nature Conservancy: Arlington, VA, USA, 1998.

11. Beadle, N.C.W.; Costin, A.B. Ecological classification and nomenclature. Proc. Linn. Soc. NSW 1952, 67, 61-82.

12. Faber-Langendoen, D.; Keeler-Wolf, T.; Meidinger, D.; Josse, C.; Weakley, A.; Tart, D.; Navarro, G.; Hoagland, B.; Ponomarenko, S.; Fults, G.; et al. Classification and Description of World Formation Types; RMRS-GTR-346; U.S. Department of Agriculture, Forest Service, Rocky Mountain Research Station: Fort Collins, CO, USA, 2016; 222p. [CrossRef]

13. Dudley, N.; Stolton, S. (Eds.) Defining Protected Areas: An International Conference in Almeria, Spain; IUCN: Gland, Switzerland, 2008; 220p.

14. Thackway, R.; Cresswell, I.D. An Interim Biogeographic Regionalisation for Australia; Version 6.0; Australian Nature Conservation Agency: Canberra, Australia, 1995. Available online: https://environment.gov.au/land/nrs/science/ibra (accessed on 26 August 2021).

15. Benson, J.S.; Allen, C.; Togher, C.; Lemmon, J. New South Wales Vegetation Classification and Assessment: Part 1 Plant communities of the NSW Western Plains. Cunninghamia 2006, 9, 383-451.

16. Benson, J.S. New South Wales Vegetation Classification and Assessment: Part 2 Plant communities in the NSW South-western Slopes Bioregion and update of NSW Western Plains plant communities. Version 2 of the NSWVCA database. Cunninghamia 2008, 10, 599-673. 
17. Benson, J.S.; Richards, P.; Waller, S.; Allen, C. New South Wales Vegetation Classification and Assessment: Part 3 Plant communities in the Brigalow Belt South, Nandewar and western New England Bioregions: Version 3 of the NSWVCA database. Cunninghamia 2010, 11, 457-579.

18. IUCN. Red List Categories: Version 3.1; Prepared by the IUCN Species Survival Commission; IUCN: Gland, Switzerland; Cambridge, UK, 2001.

19. Keith, D.A.; Rodríguez, J.P.; Rodriguez-Clark, K.; Nicholson, E.; Aapala, K.; Alonso, A.; Asmussen, M.; Bachman, S.; Basset, A.; Barrow, E.G.; et al. Scientific Foundations for an IUCN Red List of Ecosystems. PLoS ONE 2013, 8, e62111. [CrossRef]

20. Bland, L.M.; Keith, D.A.; Miller, R.M.; Murray, N.J.; Rodríguez, J.P. (Eds.) Guidelines for the Application of IUCN Red List of Ecosystems Categories and Criteria, Version 1.1; IUCN: Gland, Switzerland, 2017.

21. Andren, H. Effects of Habitat Fragmentation on Birds and Mammals in Landscapes with Different Proportions of Suitable Habitat: A Review. Oikos 1994, 71, 355-366. [CrossRef]

22. Fahrig, L. Relative Effects of Habitat Loss and Fragmentation on Population Extinction. J. Wildl. Manag. 1997, 61, 603-610. [CrossRef]

23. JANIS Joint ANZECC/MCFFA National Forest Policy Statement Implementation Sub-committee. Nationally Agreed Criteria for the Establishment of a Comprehensive, Adequate and Representative Reserve System for Forests in Australia; Commonwealth of Australia: Canberra, Australia, 1997. Available online: https://www.agriculture.gov.au/forestry/policies/rfa/about/protectingenvironment (accessed on 26 August 2021).

24. Braun-Blanquet, J. Plant Sociology: The Study of Plant Communities; Translated, revised and edited by Fuller, G.D.; Conrad, H.S. in 1983; Koeltz Scientific Books: Hesse, Germany, 1932.

25. Poore, M.E.D. The Use of Phytosociological Methods in Ecological Investigations: III. Practical Application. J. Ecol. 1955, 43, 606-651. [CrossRef]

26. Sivertsen, D. Native Vegetation Interim Type Standard; Department of Environment, Climate Change and Water: Sydney, Australia, 2009. Available online: https:/ /www.environment.nsw.gov.au/-/media/OEH/Corporate-Site/Documents/Research/Mapsand-data/native-vegetation-interim-type-standard-100060.pdf (accessed on 26 August 2021).

27. Belbin, L. The analysis of pattern in bio-survey data. In Nature Conservation: Cost Effective Biological Surveys and Data Analysis; Margules, C.R., Austin, M.P., Eds.; CSIRO: Canberra, Australia, 1991; pp. 176-190.

28. Goodall, D.W. Objective classification of vegetation II. Fidelity and indicator value. Aust. J. Bot. 1953, 1, 434-456. [CrossRef]

29. Hunter, J.T.; Hunter, V.H. Vegetation of Naree and Yantabulla stations on the Cuttaburra Creek, Far North Western Plains, New South Wales. Cunninghamia 2016, 16, 65-100. [CrossRef]

30. Department of Planning, Industry and Environment NSW. BioNet Systematic Survey. Available online: https://www. environment.nsw.gov.au/research/VISplot.htm (accessed on 26 August 2021).

31. Eco Logical Australia. NSW Vegetation Classification and Assessment (NSWVCA): Nandewar E Western New England Tablelands Bioregions; Project No. 174-001; Eco Logical Australia Pty Ltd.: Coffs Harbour, Australia, 2008.

32. Australian Government Department of Agriculture, Water and Environment. EPBC Act, Threatened Ecological Communities in New South Wales and ACT. Available online: http:/ / environment.gov.au/biodiversity/threatened/communities/NSW-ACT (accessed on 4 October 2021).

33. NSW Government, Biodiversity Conservation Act NSW, Schedule 2, List of Threatened Ecological Communities. Available online: https:/ / legislation.nsw.gov.au/view/html/inforce/current/act-2016-063\#sch.2 (accessed on 26 August 2021).

34. Department Planning, Infrastructure and Environment NSW. Bionet Vegetation Classification. Available online: https://www. environment.nsw.gov.au/research/Visclassification.htm (accessed on 4 October 2021).

35. Gellie, N.J.H.; Hunter, J.T.; Benson, J.S.; Kirkpatrick, J.B.; Cheal, D.C.; McCreery, K.; Brocklehurst, P. Overview of plot-based vegetation classification approaches within Australia. Phytocoenologia 2018, 48, 251-272. [CrossRef]

36. Geri, F.; La Porta, N.; Zottele, F.; Ciolli, M. Mapping Historical Data: Recovering a Forgotten Floristic and Vegetation Database for Biodiversity Monitoring. ISPRS Int. J. Geo-Inform. 2016, 5, 100. [CrossRef]

37. Sattler, P.S.; Williams, R.D. (Eds.) The Conservation Status of Queensland's Bioregional Ecosystems; Environmental Protection Agency: Brisbane, Australia, 1999.

38. Gowans, S.; Milne, R.; Westbrooke, M.; Palmer, G. Survey of Vegetation in Tooralie; Prepared for the NSW Government Office for Environment \& Heritage; Centre for Environmental Management University of Ballarat: Victoria, Australia, 2012.

39. Westbrooke, M.; Gowans, S.; Gibson, M. The vegetation of the Coonavitra area, Paroo Darling National Park, western New South Wales. Cunninghamia 2011, 12, 7-27.

40. Jennings, M.D.; Faber-Langendoen, D.; Loucks, O.L.; Peet, R.K.; Roberts, D. Standards for associations and alliances of the U.S. National Vegetation Classification. Ecol. Mono. 2009, 79, 173-199. [CrossRef]

41. Benson, J.S. Sampling, strategies and costs of regional vegetation vegetation mapping. The Globe 1995, 43, 18-28.

42. Berg, C.; Ewald, J.; Hobohm, C.; Dengler, J. The whole and its parts: Why and how to disentangle plant communities and synusiae in vegetation classification. Appl. Veg. Sci. 2019, 23, 127-135. [CrossRef]

43. Hunter, J.T. Temporal phytocoenosia and synusiae: Should we consider temporal sampling in vegetation classification? Aust. J. Bot. 2021. [CrossRef] 
44. Faber-Langendoen, D.; Aaseng, N.; Hop, K.; Lew-Smith, M.; Drake, J. Vegetation classification, mapping, and monitoring at Voyageurs National Park, Minnesota: An application of the U.S. National Vegetation Classification. Appl. Veg. Sci. 2007, 10, 361-374. [CrossRef]

45. Macquarie Marshes Adaptive Environment Management Plan: Synthesis of Information Projects and Actions; NSW Department of Environment Climate Change and Water: Sydney, Australia, 2010. Available online: https://www.environment.nsw.gov.au/-/ media/OEH/Corporate-Site/Documents/Water/Water-for-the-environment/macquarie-marshes-adaptive-environmentalmanagement-plan-100224.pdf (accessed on 26 August 2021).

46. Gwydir Wetlands Adaptive Environment Management Plan: Synthesis of Information Projects and Actions; NSW Department of Environment Climate Change and Water: Sydney, Australia, 2010. Available online: https://www.environment.nsw.gov.au/ - /media/OEH/Corporate-Site/Documents/Water/Water-for-the-environment/gwydir-wetlands-adaptive-environmentalmanagement-plan-110027.pdf (accessed on 26 August 2021).

47. Maguire, O.; Armstrong, R.; Benson, J.; Streeter, R.; Paterson, C.; McDonald, P.; Salter, N.; East, M.; Webster, M.; Sheahan, M.; et al. Using high resolution digital aerial imagery interpreted in a 3-D digital GIS environment to map predefined plant communities in central-southern New South Wales. Cunninghamia 2012, 12, 247-266. [CrossRef]

48. Department of Planning, Industry and Environment NSW. State Vegetation Type Map. 2021. Available online: https://www. environment.nsw.gov.au/vegetation/state-vegetation-type-map.htm (accessed on 26 August 2021).

49. Definiens Imaging GmbH eCognition User Guide 4; Definiens Imaging, GmbH: Munich, Germany, 2021; Available online: https: //www.geospatialworld.net/news/the-new-ecognition-professional-4-0/ (accessed on 26 August 2021).

50. Elith, J.; Leathwick, J.R.; Hastie, T. A working guide to boosted regression trees. J. Anim. Ecol. 2008, 77, 802-813. [CrossRef] [PubMed]

51. Ferrier, S.; Guisan, A. Spatial modelling of biodiversity at the community level. J. Appl. Ecol. 2006, 43, 393-404. [CrossRef]

52. Hunter, J.T. Validation of the Greater Hunter Native Vegetation Mapping as it pertains to the Upper Hunter region of New South Wales. Ecol. Manag. Restor. 2016, 17, 40-46. [CrossRef]

53. Benson, J.S.; Ashby, E. The vegetation of the Guyra 1:100,000 map sheet New England Bioregion, New South Wales. Cunninghamia 2000, 6, 747-872.

54. Brown, K. National Park Service vegetation inventory and use of hybrid approaches to signature development and object-oriented tools. In Proceedings of the PECORA 17-The Future of Land Imaging ... Going Operational, Denver, CO, USA, 18-20 November 2008.

55. Benson, J.S. Comprehensive, reliable vegetation classification and mapping is vital for terrestrial restoration ecology. In Restore, Regenerate, Revegetate: A Conference on Restoring Ecological Processes, Ecosystems and Landscapes in a Changing World 2018; Smith, R., Ed.; University of New England: Armidale, NSW, Austrilia, 2021; pp. 15-16. Available online: https: / / www.une.edu.au/about-une/faculty-of-science-agriculture-business-and-law / school-of-environmental-and-ruralscience/ers-news-and-events/restore-regenerate-revegetate-conference-2017 (accessed on 26 August 2021).

56. Benson, J. Classifying ecological communities and synthesizing data for natural resource management: Some problems and potential solutions. Ecol. Manag. Restor. 2008, 9, 86-87. [CrossRef]

57. Tan, J.; Li, A.; Lei, G.; Bian, J.; Chen, G.; Ma, K. Preliminary assessment of ecosystem risk based on IUCN criteria in a hierarchy of spatial domains: A case study in Southwestern China. Biol. Conserv. 2017, 215, 152-161. [CrossRef]

58. Wyborn, C.; Evans, M.C. Conservation needs to break free from global priority mapping. Nat. Ecol. Evol. 2021, 1-3. [CrossRef]

59. Margules, C.; Pressey, R. Systematic conservation planning. Nature 2000, 405, 243-253. [CrossRef] [PubMed]

60. Cowling, R.M.; Knight, A.T.; Faith, D.P.; Ferrier, S.; Lombard, A.T.; Driver, A.; Rouget, M.; Maze, K.; Desmet, P.G. Nature Conservation Requires More than a Passion for Species. Conserv. Biol. 2004, 18, 1674-1676. [CrossRef]

61. IUCN. Global Ecosystem Typology 2.0: Descriptive Profiles for Biomes and Ecosystem Functional Groups; IUCN: Gland, Switzerland, 2020. [CrossRef]

62. IPCC. Climate Change 2021. The Physical Science Basis. Contribution of Working Group I to the Sixth Assessment Report of the Intergovernmental Panel on Climate Change 2021; Masson-Delmotte, V., Zhai, A.P., Pirani, S.L., Connors, C., Péan, S., Berger, N., Caud, Y., Chen, L., Goldfarb, M.I., Gomis, M., et al., Eds.; Cambridge University Press: Cambridge, UK, 2021; Available online: https://www.ipcc.ch/report/ar6/wg1/ (accessed on 26 August 2021).

63. Noss, R. Protected areas: How much is enough? In National Parks and Protected Areas; Wright, R., Ed.; Blackwell: Cambridge, UK, 1996; pp. 91-120.

64. Locke, H. Nature needs half: A necessary and hopeful new agenda for protected areas. Parks 2013, 19, 13-22. [CrossRef]

65. Pressey, R.L.; Visconti, P.; McKinnon, M.C.; Gurney, G.G.; Barnes, M.D.; Glew, L.; Maron, M. The mismeasure of conservation. Trends Ecol. Evol. 2021, 36, 808-821. [CrossRef] [PubMed]

66. Rowland, J.A.; Nicholson, E.; Murray, N.J.; Keith, D.A.; Lester, R.E.; Bland, L.M. Selecting and applying indicators of ecosystem collapse for risk assessments. Conserv. Biol. 2018, 32, 1233-1245. [CrossRef]

67. Webb, L.J. Environmental Relationships of the Structural Types of Australian Rain Forest Vegetation. Ecology 1968, 49, $296-311$. [CrossRef]

68. Walker, J.; Hopkins, M.S. Vegetation. In Australian Soil and Land Survey: Field Handbook, 2nd ed.; Isbell, R.C., Speight, R.F., Walker, J.G., Hopkins, M.S., Eds.; Inkata Press: Melbourne, Australia, 1990; pp. 58-86, Part of Supplementary Materials S1.

69. Speight, J.G.; Isbell, R.F. Substrate. In Australian Soil and Land Survey: Field Handbook, 2nd ed.; McDonald, R.C., Isbell, R.F., Speight, J.G., Walker, J., Hopkins, M.S., Eds.; Inkata Press: Melbourne, Australia, 1990; pp. 153-170, Part of Supplementary Materials S1. 
70. Stace, H.C.T.; Hubble, G.D.; Brewer, R.; Northcote, K.H.; Sleeman, J.R.; Mulcachy, M.J.; Hallsworth, E.G. A Handbook of Australian Soils; Rellim Technical Publications: Glenside, SA, Australia, 1968; Part of Supplementary Materials S1.

71. Speight, J.G. Landformin. In Australian Soil and Land Survey: Field Handbook, 2nd ed.; McDonald, R.C., Isbell, R.F., Speight, J.G., Walker, J., Hopkins, M.S., Eds.; Inkata Press: Melbourne, Australia, 1990; pp. 9-57, Part of Supplementary Materials S1. 